\title{
Performance of Private Equity Funds in Korea*
}

\author{
Kibeum Bae, $C E O$, K-fin Asset Management \\ Junesuh Yi**, Professor, Dongguk University
}

\begin{abstract}
$\langle$ Abstract $\rangle$
This study analyzes performance of PEFs in Korea. Using the unique return data of 134 private equity funds collected from limited partners (LP) including pension funds, this study explores performance differences by investment step, strategy, timing, and fund size. This study also investigates risk adjusted return, return on economic cycles, and likelihood of performance exaggeration by general partners (GP) on liquidated funds. In addition, this paper examines factors to affect PEF performance. We find that Korean PEF records $6.12 \%$ of IRR and 1.22 of investment multiple on average. Fund performance is also found to be superior in liquidated funds by investment step, buyout funds by investment strategy, and small funds by fund size. As the result of analyzing performance of only liquidated funds, reflecting the nature of private equity funds where most of the profits are realized at the time of harvesting, we find that risk adjusted returns by measuring KS-PME, PME+, and direct alpha overperform market returns, and that funds liquidated during the recession display higher returns than funds liquidated during the boom. In terms of factors affecting performance, fund performance is negatively related to fund life, market return, and GDP growth rate.
\end{abstract}

Keywords: Private Equity; Buyout Funds; PME; Direct Alpha; IRR(Multiple)

JEL Classification: G20, G23

* This is a part of Gibeum Bae's Ph.D. dissertation at Dongguk University.

** Corresponding Author. Address: Dongguk Business School, Dongguk University, 1Gil 30, Pilding-ro, Jung-gu, Seoul, Korea 04682; E-mail: jsyieee@gmail.com; Tel: +82-2-2260-8589; Fax: +82-2-2260-3684.

Received: October 31, 2019; Revised: January 13, 2020; Accepted: January 31, 2020 


\title{
경영참여형 사모펀드 $(\mathrm{PEF})$ 의 성과분석*
}

\author{
배 기 범 (케이핀 자산운용 대표) \\ 이 준 서 (동국대학교 교수)**
}

\begin{abstract}
본 연구는 경영참여형 사모펀드 $(\mathrm{PEF})$ 의 성과를 분석하였다. 연기금 등 기관투자자 $(\mathrm{LP})$ 로부터 실제 투자내역을 직접 수집한 독점적 수익률 자료를 토대로 134 개 $\mathrm{PEF}$ 에 대해 투자단계별·투자전략별· 투자시기별·펀드규모별 성과차이를 살펴보았다. 또한 청산완료된 46개 $\mathrm{PEF}$ 를 대상으로 위험조정수익률. 경기순환에 따른 수익률· $\mathrm{GP}$ 과대보고유인 등에 대한 검증을 실시했다. 이와 함께 $\mathrm{PEF}$ 수익률에 미치는 요인에 대한 분석도 실시했다. 분석결과 국내 $\mathrm{PEF}$ 의 평균 IRR은 $6.12 \%$, 투자배수는 1.22 를 기록한 것으로 밝혀졌다. 투자단계별로는 청산완료된 펀드가, 투자전략별로는 바이아웃 펀드의 수익률이 가장 높았으며, 규모별로는 소규모 펀드의 수익률이 상대적으로 우수했다. 대부분의 수익이 회수시점에 실현되는 $\mathrm{PEF}$ 의 특성 상 청산완료된 펀드만을 대상으로 성과분석을 실시한 결과, $\mathrm{KS}-\mathrm{PME}, \mathrm{PME}+$, 다이렉트 알파 방법을 통해 산출한 위험조정수익률이 시장수익률을 초과하는 것으로 나타났다. 경기순환주기에 대한 분석에서는 불황시기에 청산된 펀드의 수익률이 더 높았다. $\mathrm{PEF}$ 수익률에 미치는 요인은 펀드수명과 시장수익률, $\mathrm{GDP}$ 성장률로 펀드수명이 짧을수록, 수명기간 동안의 시장수익률과 $\mathrm{GDP}$ 성장률이 낮을수록 수익률이 높은 것으로 밝혀졌다.
\end{abstract}

핵심 단어 : 경영참여형 사모펀드(PEF), 바이아웃, $\mathrm{IRR}($ 투자배수), $\mathrm{PME}$, 다이렉트 알파 JEL 분류기호: G20, G23

* 본 논문은 배기범의 동국대학교 박사 학위논문 중 일부임.

** 연락담당 저자. 주소: 서울특별시 중구 필동로 1 길 30 동국대학교 서울캠퍼스 경영학과, 04682; E-mail: jsyieee@gmail.com; Tel: 02-2260-8589; Fax: 02-2260-3684. 


\section{1. 서론}

사모펀드 시장이 급격하게 성장하고 있다. 2019년 10월 말 기준 사모펀드 시장의 순자산(NAV) 총액은 401조 원으로 사상 처음으로 400조 원을 넘어서면서 252조 원의 공모펀드 규모보다 1.6배나 더 커졌다. 지난 2016년 사모펀드가 공모펀드 시장규모를 추월한 이후 3년여 만에 그 차이 폭이 빠르게 확대되고 있는 것이다. 사모펀드 시장의 성장은 투자환경 악화로 인한 공모펀드 수익률 저하에 주로 기인하지만 금융당국의 사모펀드 활성화를 위한 규제 완화도 한 못을 담당하고 있다. 특히 2018년 하반기 전문투자형(헤지펀드)과 경영참여형(PEF)의 일원화를 통한 지분보유 의무나 의결권 제한에 대한 규제가 폐지되는 방향으로 제도개선이 추진되면서 향후 사모펀드 시장 확대는 더욱 가속화될 전망이다.

이 같은 사모펀드 시장의 성장은 전 세계적인 추세이다. 2018년 말 기준으로 PE(Private Equity)1), 헤지펀드, 부동산펀드, 인프라펀드, 사모사채펀드, 원자재펀드 등을 포함하는 글로벌 사모자본시장(Private Capital Market)의 총 운용자산(AUM)은 8.7조 달러로 2008년의 3.7조 달러에 비해 2.4배나 증가했다.2) 이 중 PE가 3.4조 달러, 헤지펀드가 2.9조 달러로 사모자본시장의 핵심 투자자산 역할을 담당하고 있다. 특히 과거 $\mathrm{PE}$ 의 시장규모는 헤지펀드에 비해 적었으나 글로벌 금융위기 이후 헤지펀드 규모를 넘어섰다. 글로벌 사모자본시장 규모는 향후에도 지속적으로 성장, 2023년 14조 달러에 이를 것으로 전망되고 있다.

사모자본시장을 구성하고 있는 자산 중 $\mathrm{PE}$ 는 자본시장에 직접적인 자금공급을 한다는 측면에서 다른 대체자산들에 비해 경제적 파급효과가 훨씬 더 크다. 일단 $\mathrm{PE}$ 는 기본적으로 성장자본의 역할을 수행하고 있다. 기업의 성장단계별로 요구되는 자본의 성격이나 조달규모가 상이한 상황에서 $\mathrm{PE}$ 는 $\mathrm{VC}$, 메자닌, 바이아웃 등 다양한 형태로 자금을 공급하고 있다. 또한 $\mathrm{PE}$ 는 기업 구조조정 단계에서도 자본공급 역할을 담당하기도 한다. 부실채권 매집을 통해 구조조정 과정을 주도하거나 구조조정 기업에 대한 유동성 공급을 통한 재무적 투자자 역할을 수행하기도 한다.

$\mathrm{PE}$ 의 바이아웃 형태로 설계된 $\mathrm{PEF}$ 는 실제로 2019년 6월 말 기준 약정액이 80조 원을 넘어섰으며 이행액도 60 조 원에 달해 2014년 이후 2 배 성장을 했다. PEF 수도 600 개가 넘어섰으며 운용사(GP: General Partner)수도 300여 개에 이르고 있다. 특히 사모펀드 활성화를 위한 자본시장법 개정으로 2015년 전문사모운용사의 설립요건이 자기자본 20억 원 등록만으로 완화되면서 전문사모운용사가 크게 증가하고 있다.3) 최근에는 기관투자자들의 스튜어드십 코드 도입 추세와 맞물리면서 주주권을 적극적으로 행사하려는 PEF도 등장하고 있다. 2019년

1) $\mathrm{PE}$ 는 통상적으로 장외시장에서 비상장 기업이 발행한 증권에 투자하는 자본을 의미하며, 비상장 기업의 성장단계에 따라 벤처캐피탈(VC), 성장자본(growth capital), 바이아웃(buyout), 메자닌 (Mezzanine), 부실채권(distress debt) 등을 포함한다.

2) Preqin Alternatives in 2019와 Barclays Hedge Fund 참조.

3) 금융위원회(Financial Services Commission, 2015), 전문사모운용사의 자기자본 등록요건은 2019년 1 월 자본시장법 시행령 개정을 통해 10 억 원으로 다시 완화되었다. 
Performance of Private Equity Funds in Korea

주주총회에서는 KCGI가 한진칼의 2대주주가 되면서 한진칼에 대한 주주권 행사 여부로 언론의 주목을 받은 바 있다.4)

반면 $\mathrm{PEF}$ 를 포함한 사모펀드 시장의 급격한 팽창은 금융시장의 시스템적 리스크를 증대시켜 금융안정성을 저해시킬 수 있다는 우려의 목소리도 제기된다. 실제로 $\mathrm{Yi}(2019)$ 는 사모펀드 규모의 확대가 금융안정성(FSI)에 제한적으로 악영향을 미친다는 사실을 밝혀냈다. 또한 운용자 (GP)에 대한 투자자(LP: Limited Partner)의 운용 지시, 무자격 무한책임사원(GP)의 자산운용 등 $\mathrm{PEF}$ 영업의 불법행위들이 최근 정치 문제와 결합되면서 $\mathrm{PEF}$ 를 포함한 사모펀드 시장 전체에 대한 부정적인 인식이 확산되고 있다.

이 같이 $\mathrm{PEF}$ 가 자본시장 전반에 걸쳐 그 중요성이 증대되고 투자자들의 관심이 집중되고 있음에도 불구하고 $\mathrm{PEF}$ 에 대한 연구는 매우 부족한 상황이다. 기본적으로 $\mathrm{PEF}$ 는 사모펀드임에 따라 운용자 $(\mathrm{GP})$ 가 금융당국에 최소한의 운용관련 데이터만을 제출, 관련 자료가 거의 없기 때문이다. 또한 제출된 자료마저 영업상 기밀에 해당될 수 있어 당국이 개별 GP에 대한 자료를 공개하지 않은 채 1 년에 한 차례 'PEF 동향 및 시사점'을 통해 $\mathrm{PEF}$ 시장의 통합 현황만을 알려줄 뿐이다. 이에 따라 $\mathrm{PEF}$ 시장은 깜깜이 투자자산으로 인식되고 있다.

이에 따라 본 연구에서는 어려운 과정을 거쳐 획득한 독점적이고 특별한 개별 $\mathrm{PEF}$ 의 자료를 통해 국내 $\mathrm{PEF}$ 성과에 대한 분석을 실시한다. 즉 대표적인 기관투자자(LP)로 활동하고 있는 주요 연기금과 보험사, 은행 등의 실제 투자내역으로부터 수집한 수익률 자료를 토대로 우리나라 $\mathrm{PEF}$ 의 성과를 분석한다.

구체적으로 총 134 개의 실제 $\mathrm{PEF}$ 의 수익률을 이용해 $\mathrm{PEF}$ 의 성과에 대한 실증분석을 실시한다. 즉 투자·회수·청산완료 등 투자단계별로 성과를 측정하고, 바이아웃·성장·재무안정 등 투자전략별 로도 성과차이가 발생하는지 살펴본다. $\mathrm{PEF}$ 설정년도를 $\mathrm{PEF}$ 시장 발전단계 상 준비기·도약기. 성장기로 구분하여 투자시기별 성과차이와 $\mathrm{PEF}$ 규모에 따른 대형·중형·소형 펀드간 수익률 차이 발생여부도 알아본다. 또한 $\mathrm{PEF}$ 는 일반적으로 회수시점에 실질적인 수익이 창출되므로 청산완료된 46개 펀드만을 대상으로 위험조정수익률도 측정한다. 이를 위해 현금흐름 자료를 확보하고 $\mathrm{KS}-\mathrm{PME}, \mathrm{PME}+$, 다이렉트 알파(direct alpha)등 다양한 종류의 위험조정수익률을 산출한다. 경기순환별 수익률 차이발생 여부나 투자약정을 받기 위해 흔히 발생하는 $\mathrm{GP}$ 의 성과 과대보고 여부에 대한 검증도 실시한다. 마지막으로 다양한 변수의 검증을 통해 $\mathrm{PEF}$ 수익률에 영향을 미치는 요인에 대한 분석도 실시한다.

본 연구는 국내 $\mathrm{PEF}$ 성과 측정과 관련된 최초의 연구라는 점에서 공헌점이 상당히 높다고 할 수 있다. $\mathrm{PEF}$ 관련 연구는 자료부족과 시장 미성숙으로 인해 그동안 진행되지 못하였다. 또한 다이렉트 알파 등 다양한 평가방법론을 활용해 $\mathrm{PEF}$ 의 성과를 측정해 본 점도 의의가 있다고 할 수 있다. $\mathrm{PEF}$ 의 경우 상대적 성과를 평가하기 위한 적절한 벤치마크가 존재하지 않는 상황에서, 비교적 최근 기법인 다이렉트 알파법을 활용해 위험조정수익률을 산출한 것은

4) KCGI(Korea Corporate Governance Improvement)는 일명 강성부펀드라고 불리우는 행동주의 펀드이다. 투자목적 자회사인 그레이스홀딩스를 통해 한진칼 지분 $12.01 \%$ 를 보유하고 있다. 
한국증권학회지 제49권 2호 (2020)

$\mathrm{PEF}$ 의 전반적 성과에 대한 이해 당사자들의 궁금증을 상당부분 해결해 줄 것이라고 생각한다. 이와 함께 본 연구는 사모펀드 규제완화에 대한 속도조절 필요성, 투자자와 운용자의 적절한 $\mathrm{PEF}$ 투자와 운용을 위한 정보 제공, $\mathrm{PEF}$ 의 지배구조 개선 역할, $\mathrm{PEF}$ 객관적 자료에 대한 공시 필요성 등 $\mathrm{PEF}$ 와 관련된 정책적 시사점도 제시할 것으로 기대한다.

본 연구의 구성은 다음과 같다. 제 2장에서는 $\mathrm{PEF}$ 시장 현황에 대해 살펴보고 제 3 장에서는 선행연구를 정리한다. 제 4장에서는 자료와 방법론에 대해 설명하고 제 5 장에서는 실증분석 결과를 기술한다. 제 6장에서는 결론과 정책적 시사점에 대해 논한다.

\section{2. $\mathrm{PEF}$ 시장 현황}

자본시장법 상 경영참여형 사모집합투자기구로 적시되어 있는 $\mathrm{PEF}$ 는 해외의 $\mathrm{PE}$ 중 바이아웃 펀드형태를 중심으로 2004년 도입되었다.5) $\mathrm{PEF}$ 시장은 준비기, 도입기를 거쳐 성장기에 접어들면서 시장 확대가 본격적으로 이루어지고 있다. 특히 2015년 사모펀드 활성화를 위한 제도개편으로 $\mathrm{PEF}$ 시장은 제 2 의 도약기를 맞고 있다. 설립이 등록제에서 보고제로 전환되었고, $\mathrm{SPC}$ 를 설립하여 전략적 투자를 할 수 있게 되었으며, 자산의 $30 \%$ 까지 증권투자를 할 수 있게 하였다. 금융전업그룹에 대한 $\mathrm{PEF}$ 운용규제가 완화되었으며 적격투자자에 대한 자격조건도 완화하였다. 2017년에는 자산의 50\% 이상을 창업벤처기업 등 중소기업에 투자하는 창업벤처전문 $\mathrm{PEF}$ 도 도입되었다.

이에 따라 2019년 6월 말 기준 PEF 수는 총 636개, 출자 약정액은 81조 원, 이행액은 58.1조 원을 기록하고 있다. <그림 $1>$ 과 같이 2009년 대비 10년 만에 PEF수는 5.8배, 약정액은 4배, 이행액은 4.5배 증가했다. 특히 PEF 수는 2015년 이후 증가세가 뚜렷하게 나타난다. 이는 PEF 설립 운용과 관련된 규제가 완화되고 창업전문 $\mathrm{PEF}$ 도입에 기인한 것으로 풀이된다. 또한 약정액 대비 이행액 비율을 나타내는 이행비율도 지속적으로 상승하고 있다. 하지만 사모펀드 전체의 성장율에 비하면 $\mathrm{PEF}$ 의 성장률은 이에 다소 못 미친다. 사모펀드의 순자산총액(NAV) 대비 PEF의 약정액(이행액) 비율은 2019년 6월 말 기준으로 22.7\%(16.7\%)로 지속적인 하향세를 보이고 있다. 이는 사모펀드 활성화 대책의 직접적인 효과가 경영참여형보다 전문투자형에서 나타나기 때문으로 풀이된다.

이 같이 약정액이나 이행액의 증가비율보다 $\mathrm{PEF}$ 수의 증가비율이 더 높음에 따라 $\mathrm{PEF}$ 규모는 소형화되고 있다. <표 1>에서와 같이 2019년 3월 기준 약정액 3천억 원 이상인 대형 $\mathrm{PEF}$ 는 58개로 전체 $\mathrm{PEF}$ 의 $9.5 \%$ 를, 약정액 1천억 원 미만인 소형 $\mathrm{PEF}$ 는 407 개로 $66.5 \%$ 를 차지하고 있다. 대형 $\mathrm{PEF}$ 비율이 $20 \%$ 이고 소형 $\mathrm{PEF}$ 비율이 $50 \%$ 내외였던 2011년과 비교하면

5) 자본시장법 도입 이전인 2004 년 10 월 '간접투자자산 운용업법' 개정을 통해 법적 근거를 마련했다. 당시 IMF 외환위기 이후 기업에 대한 대규모 구조조정이 진행되면서 부실기업 및 금융기관의 부실채권 정리를 위해 다양한 기업구조 조정기구가 마련되어 있었으나, 기존 기업구조조정기구를 통해서는 자금조성 및 투자·운영 전반에 대해 포괄적인 자율성이 부여되는 종합적인 구조조정을 할 수 없어 $\mathrm{PEF}$ 를 도입했다. 
Performance of Private Equity Funds in Korea

확실히 소형 $\mathrm{PEF}$ 가 증가하고 있는 것을 알 수 있다. 이에 따라 신설 $\mathrm{PEF}$ 의 평균 약정액은 2015년 1,342억 원이었으나 2018년에는 830억 원으로 급감했다. 이는 신규 GP가 경험이 부족하여 투자자 모집에 상대적으로 부담이 적은 소형 $\mathrm{PEF}$ 를 운용하기 때문으로 풀이된다.

〈그림 1〉PEF 연도별 현황

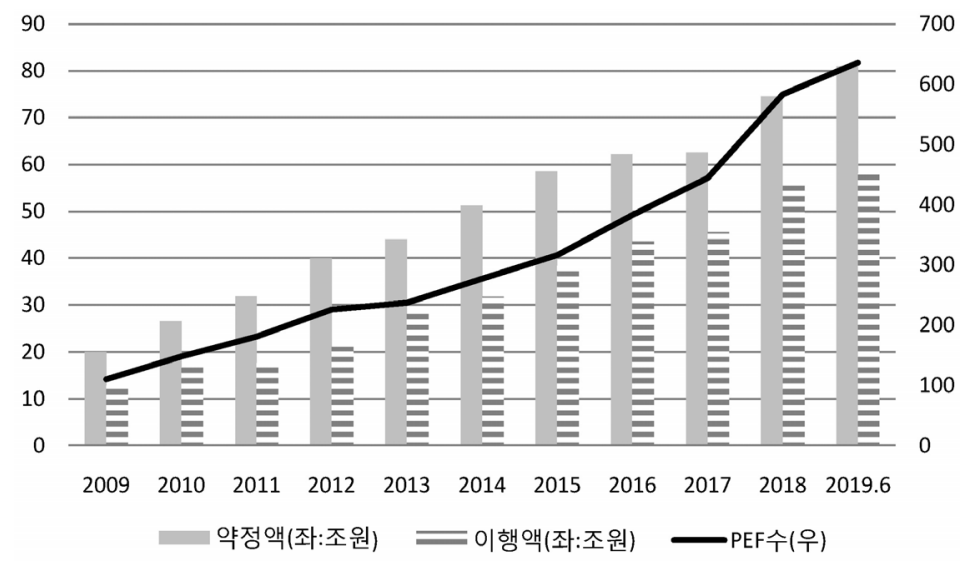

출처: 금융감독원(Financial Supervisory Service, 2019).

〈표 1〉PEF 규모별 현황

\begin{tabular}{|c|c|c|c|c|c|c|c|c|c|c|}
\hline 구분 & 출자약정 액 & 2011 & 2012 & 2013 & 2014 & 2015 & 2016 & 2017 & 2018 & 2019.3 \\
\hline 대형 & 3,000 억 원 이상 & 36 & 45 & 47 & 51 & 57 & 53 & 48 & 58 & 58 \\
\hline 중형 & 1,000 억 원 3,000 억 원 & 50 & 63 & 76 & 100 & 115 & 127 & 130 & 146 & 147 \\
\hline 소형 & 1,000 억 원 미만 & 95 & 118 & 114 & 126 & 144 & 203 & 266 & 379 & 407 \\
\hline & 계 & 181 & 226 & 237 & 277 & 316 & 383 & 444 & 583 & 612 \\
\hline
\end{tabular}

출처: 금융감독원(Financial Supervisory Service, 2019).

또한 전문운용사 설립 요건 완화로 인해 <표 $2>$ 와 같이 GP 중 전업 GP 비율은 증가하고 있는 반면 금융회사 비율은 감소하고 있다. 한편 1 조 원 이상의 초대형 $\mathrm{PEF}$ 는 총 10 개이다.6)

〈표 2〉 GP 구성 현황

\begin{tabular}{|c|c|c|c|c|c|}
\hline 구분 & 2015년 말 & 2016년 말 & 2017년 말 & 2018년 말 & 2019년 3월 말 \\
\hline 전업 & 94사 (56.3\%) & 115사(60.5\%) & 138사(66.0\%) & 170사(66.4\%) & 178사(65.7\%) \\
\hline 금융 & 41사 (24.5\%) & 41사(21.6\%) & 35사(16.8\%) & 37사(14.5\%) & 39사(14.4\%) \\
\hline 창투계회사 & 32사 (19.2\%) & 34사(17.9\%) & 36사(17.2\%) & 49사(19.1\%) & 54사(19.9\%) \\
\hline 계 & 167사 (100\%) & 190사 (100\%) & 209사(100\%) & 256사(100\%) & 271사 (100\%) \\
\hline
\end{tabular}

출처: 금융감독원(Financial Supervisory Service, 2019).

6) 최대 규모의 $\mathrm{PEF}$ 는 2009년 설립된 케이디비밸류제육호로 $\mathrm{GP}$ 는 한국산업은행이고 출자약정액은 2.75 조 원이다. 
자금모집(fund raising)은 <그림 2>에서와 같이 매년 10조 원 내외를 유지하다 2018년에는 16.4 조 원으로 2017 년 대비 6.5조 원이 증가하면서 사상 최대치를 기록했다. 또한 신설된 PEF도 2018년에 198개로 2017년의 135개에 비해 큰 폭으로 증가했다. 2018년에 신설된 PEF 중 프로젝트 $\mathrm{PEF}$ 는 147 개로 블라인드 $\mathrm{PEF} 51$ 개를 크게 앞섰다.7) $\mathrm{PEF}$ 초기에는 블라인드 $\mathrm{PEF}$ 가 더 많았으나 투자실적보다 손실방어 투자가 가능한 프로젝트 PEF에 대한 선호가 강해지면서 2013년 이후에는 프로젝트 $\mathrm{PEF}$ 의 비율이 꾸준히 증가하고 있다.

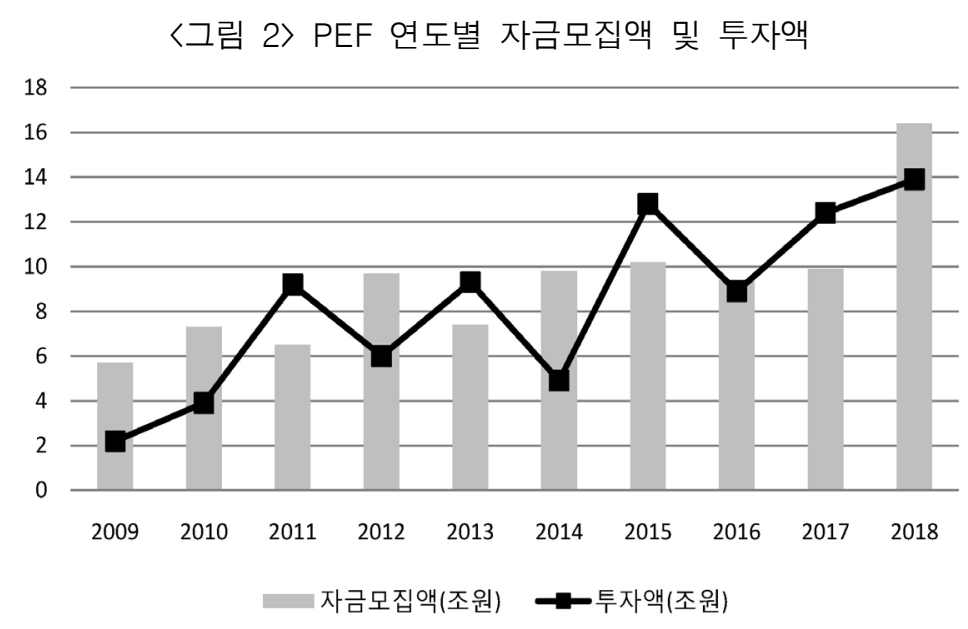

출처: 금융감독원(Financial Supervisory Service, 2019).

$\mathrm{PEF}$ 투자집행 규모는 연도별로 10조 원을 상회하고 있으며 2018년에는 13.9조 원을 기록했다. 이는 2018년에 SK해운이나 ADT캡스 등에 대한 대형거래가 발생한데 기인한다. 투자대상기업은 지난해 총 408 개였으며 국내기업이 $87 \%$ 로 대다수를 차지했다. 업종으로는 제조업 비중이 $39.7 \%$ 로 가장 높아 과학, 기술업종이 주 대상인 해외 $\mathrm{PEF}$ 와는 다소 다른 양상을 보였다. 약정액 증가로 미집행 약정액(dry powder)은 지속적으로 증가하고 있지만 최근 프로젝트 $\mathrm{PEF}$ 증가 추세로 미집행 약정비율은 감소하고 있다.

$\mathrm{PEF}$ 업력 증가로 회수액도 매년 증가하고 있다. 회수액은 <그림 3>에서와 같이 2014년까지는 연 4조 원대에 머물렀으나 최근 증가, 지난해에는 9조 원을 기록했다. 특히 지난해 KTB PE가 보유하고 있던 전진중공업 지분을 웰투시인베스트먼트에 2,563억 원에 매각8)하면서 국내 $\mathrm{PEF}$ 간 첫 대형거래를 성사, 향후 세컨더리 시장의 가능성을 보여주었다. 해산하는 $\mathrm{PEF}$ 수도 지속적으로 증가하고 있으며 지난해에는 총 55 개 $\mathrm{PEF}$ 가 해산되었다. 존속기간 만료로 해산된 $\mathrm{PEF}$ 도 다수를 차지하고 있지만 적정한 투자처를 찾지 못해 해산하지 못하고 만기가 연장되는 PEF 또한 증가하고 있는 것으로 알려지고 있다.

7) 블라인드 $\mathrm{PEF}$ 는 $\mathrm{PEF}$ 설립 시 투자대상을 정하지 않고 $\mathrm{GP}$ 의 운용능력을 기초로 투자자를 모집한 후 투자대상을 선정하는 $\mathrm{PEF}$ 이고, 프로젝트 $\mathrm{PEF}$ 는 투자대상을 사전에 정하고 설립하는 $\mathrm{PEF}$ 이다. 8) 이데일리 'PEF에서 PEF로 손바뀜', 늘어나는 세컨더리 딜, 2019년 5월 16일자. 


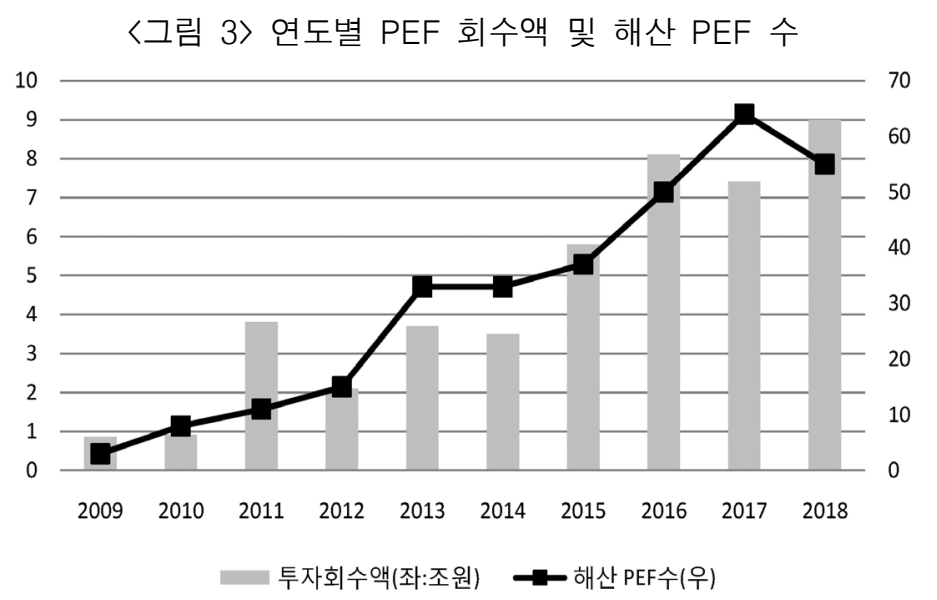

출처: 금융감독원(Financial Supervisory Service, 2019).

\section{3. 선행연구}

$\mathrm{PEF}$ 와 관련된 국내연구는 거의 없는 실정이다. $\mathrm{PEF}$ 는 사모펀드로 공모펀드와 달리 펀드 운용과 관련된 공시의무가 없으므로 $\mathrm{LP}$ 를 제외하고는 펀드운용 정보를 확인하기 어렵다. 또한 $\mathrm{PEF}$ 가 투자하는 대상 중에 상당부분이 비상장주식이므로 객관적인 가치 평가가 곤란해 실제 $\mathrm{IPO}$ 나 매각을 통한 청산이 이루어지기 전까지는 수익률도 확인되지 않는다. 이에 따라 상대적으로 자료 접근이 가능한 벤처캐피탈이나 외국자료를 활용한 해외 $\mathrm{PEF}$ 에 대한 연구만이 존재할 뿐이다.

Lee and Han(2013)은 창업투자회사가 결성한 펀드와 청산이 완료된 벤처펀드 자료를 가지고 경기대응적, 최상위 운용사 선정, $\mathrm{PE}$ 펀드 포트폴리오 분산 등 벤처펀드의 투자전략에 대한 연구를 진행했다. 이 보다 앞서 Park and Yoon(2012)은 한국 모태펀드의 운용현황과 투자성과를 분석했다. $\mathrm{Yi}(2017)$ 는 2015년 10월 제도 개편으로 $\mathrm{PEF}$ 가 경영참여형 사모펀드로 분류되기 이전에 절대수익추구형, 부동산형, 기타형 등 대체투자 성격을 지닌 사모펀드에 대한 성과를 분석한 바 있다.

실질적인 PEF와 관련해서는 Song et al.(2014)이 Prequin 자료를 통해 국내 자료가 아닌 $\mathrm{PEF}$ 를 포함한 글로벌 사모펀드의 전략별 성과분석을 실시했으며 Song et al.(2015)은 동일한 자료를 이용해 전략별 지역별로 수익과 위험의 특성이 상이하게 나타나 분산투자 효과가 나타날 수 있음을 보였다.

$\mathrm{PEF}$ 에 대한 해외연구도 자료 제약 상 그다지 활발하게 진행되지는 못하고 있다. 다만 새로운 자료가 등장할 때마다 연구가 진행되고 있으며 자료에 따라 연구결과가 다소 상이하게 도출되고 있다. PEF 성과와 관련된 최초의 연구는 Kaplan and Schoar(2005)로 그들은 Thomson Venture Economics 자료를 활용해 $\mathrm{LBO}$ (Leveraged Buyout)와 $\mathrm{VC}$ (Venture Capital)의 성과를 측정, 보수차감 전에는 시장수익률(S\&P500)을 초과했으나 보수차감 후에는 시장수익률과 거의 동일하다고 주장했다. 또한 펀드별로 성과차이가 크게 발생했으며 이행자본 가중 수익률의 경우 LBO는 시장수익률을 하회했다고 밝혔다. 이어 Phalippou and Gottschalg(2009)도 동일 
한국증권학회지 제49권 2호 (2020)

자료를 활용해 $\mathrm{PEF}$ 성과가 보수차감 후 S\&P500에 비해 연 평균 3\%, 위험조정 후 $6 \%$ 나 하회한다고 주장했다.

반면 Robinson and Sensoy(2013)은 실제 LP자료를 이용해 PEF의 성과를 측정한 결과 $\mathrm{LBO}$ 나 VC 모두 시장수익률을 초과하는 사실을 밝혀냈다. 또한 Higson and Stucke(2012)는 Cambridge Associate의 새로운 현금흐름 자료를 활용해 PEF가 지속적으로 초과성과를 나타냄을 보였다. 이같이 $\mathrm{PEF}$ 의 성과가 시장수익률을 하회 또는 상회하는 상반된 결과에 대해 그 원인을 밝혀낸 논문이 Harris et al.(2014)의 연구이다. 이들은 Burgiss라는 새로운 자료를 이용해 1,400 여 개에 이르는 $\mathrm{PEF}$ 와 $\mathrm{VC}$ 의 성과를 분석, $\mathrm{S} \& \mathrm{P} 500$ 대비 초과성과는 펀드 수명 동안 $20 \%$ 를 초과했으며 연 $3 \%$ 를 넘는다는 사실을 밝혀냈다. 이들은 $\mathrm{PEF}$ 자료 제공사들의 데이터를 비교, Cambridge Associates 및 Preqin의 성과는 Burgiss와 질적으로 유사하지만 Thomson Venture Economics은 Burgiss에 비해 낮게 나타난다는 사실을 지적하였다. 즉 Thomson Venture Economics의 경우 현금흐름과 순자산가치(NAV)를 업 데이트하지 않아 $\mathrm{PEF}$ 의 성과가 하향편의될 가능성이 존재함을 밝혀냈다.

\section{4. 자료 및 방법론}

\section{1 자료}

$\mathrm{PEF}$ 성과에 대한 자료는 대형 연기금이나 보험사 등 주요 LP 기능을 하는 기관들로부터 직접 수집했다.9) 즉 해당 $\mathrm{PEF}$ 에 직접 투자한 $\mathrm{LP}$ 들로부터 기존의 투자자료를 제공받는 방식으로 데이터를 확보했다. 이에 따라 표본은 전체 $\mathrm{PEF}$ 의 시장현황에 비해 상대적으로 청산이 완료되었거나 회수단계에 있는 펀드들 위주로 구성되었다.

기관투자자들의 $\mathrm{PEF}$ 투자관련 자료는 개인투자자들에 비해 체계적으로 관리되므로 비교적 신뢰성이 높다. 물론 $\mathrm{PEF}$ 운용과 관련한 모든 내역을 관리하는 $\mathrm{GP}$ 나 사무관리사들의 자료가 보다 정확하겠으나 강력한 정보 보호법으로 인해 자료취득이 거의 불가능하다. LP 자료는 이 같은 정보 환경을 감안할 때 현실적으로 획득할 수 있는 차선의 자료라고 할 수 있다.

2017년 말 기준으로 청산되었거나 현재 투자진행 중인 PEF 중 이들 기관투자자들로부터 직접 제공받은 $\mathrm{PEF}$ 수는 총 194 개였다. 이 중 회사형 투자신탁, 투자조합 등 일반 $\mathrm{PEF}$ 와 투자형태가 상이하거나 기관들이 중복 LP로 투자하여 복수로 수집된 펀드, 그리고 최종 수익률 자료가 누락된 펀드를 제외하고 141 개의 $\mathrm{PEF}$ 를 고려하였다. 기초통계분석 결과 수익률이 이상치(outlier) 값을 보인 펀드10)를 제외하고 최종적으로 134 개의 표본을 선정하였으며 이들

9) $\mathrm{LP}$ 의 정보보호를 위해 실제 기관명이나 기관수를 밝히지 못하는 점에 대해 양해를 구한다.

10) IRR 및 투자배수가 표본 평균으로부터 표준편차의 2 배 이상 및 이하인 펀드. 사모펀드의 경우 공모펀드에 비해 고수익, 고위험을 추구한다는 측면에서 이 같은 수익률 극단치의 제거는 논란을 일으킬 수 있다. 하지만 본 연구에서 제거된 표본의 경우 대부분 청산완료가 되지 않은 투자단계나 회수단계에 있는 펀드들로 수익이 확정되지 않은 상태에서의 이상치를 보임에 따라 제외시켰다. 즉 투자단계에 있는 펀드 중 일부 펀드의 경우 투자배수가 2.67에 이르는 등 극단적인 우수성을 보였고 청산기간이 경과했음에도 청산되지 못한 일부 펀드의 경우 $-46 \%$ 의 IRR로 극단적인 열위성을 보였다. 
Performance of Private Equity Funds in Korea

표본의 약정액 합은 37.3조 원에 달했다. 2004년부터 2017년 말까지 설정된 PEF가 총 701개이고 약정액 누계가 91.2 조 원인 것을 감안한다면 본 표본이 전체 $\mathrm{PEF}$ 에서 차지하는 비중은 펀드 수 $19.1 \%$, 약정액 $39 \%$ 로 적지 않은 수치이다.

자료는 $\mathrm{PEF}$ 명, GP명, 투자단계, 투자전략 등이 표시되어 있으며 펀드규모, 설정일, 청산일과 성과지표인 IRR 및 투자배수의 연수익률과 누적수익률 등의 정보를 포함하고 있다. 수익률은 보수 차감 후(net of fee)로 산출한다.

투자단계는 투자, 회수, 청산, 청산완료 등 4단계로 구분한다. 자료수집 기준일인 2017년 말을 기준으로 $\mathrm{PE}$ 가 설립되어 자금모집과 투자가 최초로 이루어지는 '투자단계'는 펀드 설정일로부터 5 년 이내의 기간에 해당하는 펀드들이다. 설정일로부터 5년이 경과하고 펀드의 일반적인 만기에 해당하는 10 년까지의 기간에 해당하는 펀드는 '회수단계'로 구분하며, 10 년을 경과하고도 청산되지 않은 펀드는 '미청산단계'로 분류한다. '청산완료'펀드는 청산과 분배가 완료되어 수익률이 최종 확정된 펀드들이다.

투자전략은 바이아웃(buyout), 성장(growth), 기업재무안정, 그리고 기타로 구분한다. 바이아웃 펀드는 기업의 지분을 인수하여 구조조정 혹은 타 기업과의 합병 등을 통해 기업가치를 높인 뒤 지분이나 회사를 매도하여 수익을 얻는 것을 목적으로 한다. 국내 $\mathrm{PEF}$ 는 대부분 바이아웃 형태이다. 성장전략 펀드는 성장이 빠를 것으로 예상되는 산업이나 기업에 대해 초기지분투자를 통해 수익을 얻는 것을 목적으로 하는 펀드이다. 재무안정 펀드는 특정 기업의 재무구조를 개선하는데 자금을 공급할 목적으로 구성된 펀드를 의미한다.

성과지표는 IRR과 투자배수로 측정한다. IRR은 GP에 지불된 수수료 및 성과보수(carried interest)를 차감하고 펀드에 대한 투자금 및 분배금을 기반으로 $\mathrm{LP}$ 의 연간 내부수익률을 측정한 것이다. 펀드에 대한 모든 투자가 실현되고 현금이 투자자에게 반환될 때까지, IRR 계산에는 마지막 보고일 현재의 미실현 투자(잔여 순자산 가치)의 추정 가치가 포함된다. 투자배수는 투자자의 모든 펀드 투자액 대비 분배액의 합계와 잔여 순자산가치(NAV)에서 수수료 및 성과보수를 차감한 금액의 비율이다. 즉 투자금대비 회수액 정도를 나타낸다.

〈표 3〉표본의 투자단계 및 투자전략별 구분

\begin{tabular}{|c|c|c|c|c|c|}
\hline 투자단계 & 개수 & 금액(억 원) & 투자전략 & 개수 & 금액(억 원) \\
\hline 투자 & 43 & 115,434 & 바이아웃 & 82 & 238,557 \\
\hline 회수 & 36 & 111,728 & 성장 & 44 & 97,414 \\
\hline 미청산 & 9 & 45,049 & 재무안정 & 3 & 7,000 \\
\hline 청산완료 & 46 & 83,982 & 기타 & 5 & 13,222 \\
\hline 합계 & 134 & 356,192 & 합계 & 134 & 356,192 \\
\hline
\end{tabular}

134 개 표본의 투자단계 및 투자전략별 분포는 <표 3>에 정리되어 있다. 투자단계로는 청산완료된 펀드가 가장 많은 46개이고 회수단계가 36개, 투자단계가 43개이다. 아무래도 LP가 직접 투자한 펀드에 대한 자료를 대상으로 함에 따라 청산완료 펀드가 다수를 차지했다. 설정 년도별 투자단계를 살펴보면 투자진행 중인 펀드는 2013년부터 설정된 펀드들이고 회수단계에 
한국증권학회지 제49권 2호 (2020)

있는 펀드는 2008년부터 2013년까지 설정된 펀드들이다. 청산완료된 펀드들은 2005년부터 2016년까지 설정된 펀드들이다.11) 투자전략별 구분에서는 바이아웃 펀드가 절대다수를 차지, 국내 $\mathrm{PEF}$ 시장은 바이아웃 중심이라는 것이 증명되었다. 성장펀드는 44 개이었으며 재무안정 $\mathrm{PEF}$ 는 3 개에 그쳤다. 기타에는 자원개발, 선박투자, 세컨더리 등이 포함된다.

펀드규모와 수익률지표의 기초통계량은 <표 $4>$ 에 정리되어 있다. $\mathrm{PEF}$ 의 평균규모는 2,658 억 원이었으며 중위값은 2 천억 원으로 펀드규모가 비교적 큰 것으로 밝혀졌다. 가장 큰 펀드는 1 조 3,210 억 원이었으며 가장 작은 펀드는 153 억 원이었다. 1 조 원이 넘는 초대형펀드도 4 개가 있었으며 1,000 억 원 미만의 소형펀드는 31 개에 달했다. 내부수익률은 평균 $6.12 \%$ 를 기록했다. 가장 수익률이 높은 펀드는 $46.42 \%$ 를 기록했고 가장 수익률이 낮은 펀드는 $-30.31 \%$ 를 기록했다. 내부수익률의 중앙값은 $5.16 \%$ 였으며 마이너스 수익률을 보인 펀드 수도 27 개(20.2\%)였다. 투자배수의 경우 최대는 투자금액의 두 배가 넘는 2.35 를 기록했으며 최소펀드는 투자금액의 절반에도 미치지 못하는 0.42 였다. 투자배수가 투자금액의 두 배 이상인 펀드는 6 개였으며 투자배수가 1미만으로 투자원금을 회수하지 못한 펀드는 26개에 달했다.

〈표 4〉표본의 기초통계량

\begin{tabular}{lrrrrr}
\hline \multicolumn{1}{c}{ 구분 } & 최소 & 최대 & 평균 & 중위값 & 표준편차 \\
\hline 펀드규모(억 원) & 153 & 13,210 & 2,658 & 2,000 & 2,430 \\
$\mathrm{IRR}(\%)$ & -30.31 & 46.42 & 6.12 & 5.16 & 10.57 \\
투자배수 & 0.42 & 2.35 & 1.22 & 1.16 & 0.33 \\
\hline
\end{tabular}

\section{2 방법론}

$\mathrm{PEF}$ 수익률의 경우 적절한 비교대상이 없다. 펀드 특성 상 절대수익을 추구하므로 벤치마크의 존재가 필요없기 때문이다. 하지만 $\mathrm{PEF}$ 성과를 이해하기 위해서는 상대적 수익률도 필요하다. 이에 따라 일반적으로 IRR이나 투자배수 이외에 PME(Public Market Equivalent: 공개시장 등가)가 활용된다. $\mathrm{PME}$ 는 공개시장 벤치마크나 인덱스 수익률과의 비교를 통해 $\mathrm{PEF}$ 성과를 측정하는 방식이다. 즉 $\mathrm{PEF}$ 의 출자금 및 분배금 등 현금이 발생한 시점에 공개시장 지수에 투자되는 것으로 가정하여 수익률을 산출하는 것이다. $\mathrm{PME}$ 가 내포하고 있는 산출방식에서의 여러 가지 문제점들을 보완하면서 $\mathrm{PME}+, \mathrm{KS}-\mathrm{PME}, \mathrm{mPEM}$ (modified)등 PME계열은 다양한 형태로 진화하고 있다. 또한 다이렉트 알파(direct alpha) 방식과 같이 CAPM에서의 젠슨 알파(Jensen's alpha)와 동일한 방식으로 위험요인을 감안한 수익률을 산출하기도 한다. 따라서 본 연구에서는 PEF 성과를 IRR이나 투자배수 이외에 다양한 방법론을 활용해 $\mathrm{PEF}$ 의 진정한 성과를 측정한다.

우선 KS-PME를 통해 성과를 산출한다. KS-PME란 Kaplan and Schoar(2005)가 개발한 것으로 초과수익률의 연율화된 값을 구하는 것이 아니라 출자액 대비 수취액 계산 시 각 현금흐름을

11) 설정년도별 투자단계 현황은 <부록 $1>$ 을 참고하라. 
벤치마크 수익률로 할인하여 그 비율을 산출한다. 즉 식 (1)과 같이 펀드의 출자액과 수취액이 평가 시점의 시장수익률로 할인한 값을 통해 현재가치로 환산된다.

$$
K-S P M E_{T}=\frac{\sum_{t=0}^{T}\left(\frac{d_{t}}{1+R_{M, t}}\right)}{\sum_{t=0}^{T}\left(\frac{c_{t}}{1+R_{M, t}}\right)}
$$

여기서 $d_{t}$ 는 수취액, $c_{t}$ 는 출자액, $R_{M, t}$ 는 시장수익률이다. 따라서 $\mathrm{KS}-\mathrm{PME}$ 가 1 보다 크면 시장보다 우수한 성과를, 1 보다 작으면 시장보다 열위의 성과를 나타내게 된다.

두 번째로 PME+방법을 통해서도 수익률을 산출한다. PME+는 Rouvinez(2003)가 개발한 것으로 공개시장 투자 금액의 최종 순자산가치가 $\mathrm{PEF}$ 금액과 같아지도록 현금흐름 금액에 고정조정계수(fixed scaling factor)를 적용하여 조정한 수익률이다. PME 계산 시 사용되는 공개시장 투자분에서 잠재적으로 나타날 수 있는 숏 포지션과 롱 포지션의 비합리성을 조정하게 되는 것이다. 이를 통해 펀드의 잔존가치와 가상의 공개시장 포트폴리오의 평가금액을 일치시킬 수 있다. 매 기간 $\mathrm{PEF}$ 의 잔존가치와 가상적인 연관 포트폴리오의 잔존가치를 일치시키기 위해 $\mathrm{PEF}$ 로부터의 분배금에 고정조정계수를 적용해 수정한다. 즉 $\mathrm{PME}+$ 방법에서 순자산가치는 다음 식 (2)를 통해 도출된다.

$$
N A V_{P M E+, t}=\sum_{s=0}^{t}\left[\left(c_{s}-\lambda_{T} \cdot d_{s}\right) \cdot\left(\frac{I_{t}}{I_{s}}\right)\right]
$$

여기서, $\lambda_{T}=\frac{\left(S_{c}-N A V_{P E, T}\right)}{S_{d}}$ 는 고정조정계수를 의미하며 $S_{d}=\sum_{s=0}^{T}\left[d_{s} \cdot\left(\frac{I_{T}}{I_{s}}\right)\right], S_{c}=\sum_{s=0}^{T}\left[c_{s} \cdot\left(\frac{I_{T}}{I_{s}}\right)\right]$ 으로 계산된다. $d_{s}$ 는 수취액, $c_{s}$ 는 출자액, $I_{s}$ 는 시장지수이다.

마지막으로 다이렉트 알파 방법을 통해서도 PEF의 성과를 측정한다. Gredil et al.(2014)에 의해 고안된 다이렉트 알파 방법은 $\mathrm{CAPM}$ 의 식을 통해 위험조정수익률을 산출한다는 점에서 의의가 있다. 즉 $\mathrm{PE}$ 포트폴리오가 선택한 연관 벤치마크와 관련하여 연속 로그 수익률 관점에서 정확한 알파 계산을 가능하게 해준다. $\mathrm{PE}$ 포트폴리오의 실제 출자금 및 분배금은 만기일까지 시장 지수의 수익률에 따라 복리화되며, 최종 순자산가치와 결합하여 일련의 미래 현금 흐름 가치를 형성한다.

다이렉트 알파방식은 현재 포트폴리오 이론의 알파 정의로부터 도출된다.

$$
r(t)=b(t)+\alpha
$$

따라서 수익률 $(r)$ 은 시장수익 지수율 $(b)$ 과 알파 $(\alpha)$ 의 합이다. 다이렉트 알파 관점에서 $r(t)$ 와 $b(t)$ 는 연속함수가 되고 이에 따라 $t_{n}$ 시점의 현금흐름 $c_{i}$ 의 가치는 다음 식 (4)와 같이 나타낼 수 있다. 


$$
v_{i}\left(t_{n}\right)=c_{i} \cdot e^{\int_{t_{i}}^{t_{n}}(b(t)+\alpha) d t}
$$

벤치마크의 가치 $\frac{I_{n}}{I_{i}}=e^{\int_{t_{i}}^{t_{n}} b(t) d t}$ 를 활용하면 $v_{i}\left(t_{n}\right)=c_{i} \cdot \frac{I_{n}}{I_{i}} e^{\int_{t_{i}}^{t_{n}} \alpha d t}$ 가 된다. 적분을 풀고 시간 변수를 $t_{i}=i \Delta$ 로 이산화시키면 $v_{i}\left(t_{n}\right)=c_{i} \cdot \frac{I_{n}}{I_{i}} e^{\alpha(n-i) \Delta}$ 가 된다. 이 식을 $\mathrm{PEF}$ 의 매 출자액에 적용시키면 $\mathrm{NAV}$ 는 $N A V_{P E F}=\sum_{i=0}^{n} c_{i} \cdot \frac{I_{n}}{I_{i}} e^{\alpha(n-i) \Delta}$ 가 된다. 여기서 $(1+\alpha)=e^{\alpha \cdot \Delta}$ 라고 정의하면 다음 식 (5)가 도출된다.

$$
N A V_{P E F}=\sum_{i=0}^{n} c_{i} \cdot \frac{I_{n}}{I_{i}}(1+\alpha)^{n-i}
$$

식 (5)는 전형적인 IRR 식이 된다. 다이렉트 알파는 벤치마크로 할인된 현금흐름을 통해 도출된 IRR에 자연로그를 취해 산출할 수 있다. 즉

$$
\begin{aligned}
& a=\operatorname{IRR}\left[F V(C), F V(D), N A V_{P E F}\right] \\
& \alpha=\frac{\ln (1+a)}{\Delta}
\end{aligned}
$$

가 되는 것이다.

\section{5. 연구결과}

\section{1 수익률 특성 분석}

본 절에서는 134 개 $\mathrm{PEF}$ 의 수익률 특성에 대한 분석 결과를 기술한다. 투자·회수·청산 등 투자단계별 성과차이와 바이아웃 또는 성장 등 투자전략별 IRR과 투자배수의 상이성을 살펴 보았다. 또한 준비·도약·성장기 등 투자시기를 구분하여 $\mathrm{PEF}$ 시장 발전단계별 성과 차이 여부와 펀드 규모별 수익률 차이여부를 검증하였다.

\subsection{1 투자단계별}

앞에서 설명한 바와 같이 $\mathrm{PEF}$ 는 투자과정에 따라 4단계로 구분된다. 투자, 회수, 미청산, 청산완료 등 투자단계별 수익률 현황은 <표 5>에 정리되어 있다.

분석결과 예상한 바와 같이 청산완료된 펀드의 수익률이 가장 높았다. 청산완료 펀드의 IRR은 $10.57 \%$ 였으며 투자배수는 1.35 였다. 반면 미청산단계 펀드들의 성과가 가장 낮았다. 미청산 펀드의 IRR은 $-1.72 \%$ 를 기록했고 투자배수는 회수액이 투자금에 미치지 못하는 0.98 을 기록했다. 또한 회수단계가 투자단계보다는 높은 수익률을 보였다. 투자단계별 IRR과 투자배수의 평균과 중앙값은 모두 $1 \%$ 수준에서 통계적으로 유의하게 차이가 발생하는 것으로 나타났다. 또한 청산완료 펀드와 투자, 회수, 미청산 등 아직 청산이 완료되지 않은 펀드들간의 수익률 비교에서도 
Performance of Private Equity Funds in Korea

청산완료 펀드의 수익률이 투자나 회수진행 중인 펀드에 비해 통계적으로 유의하게 높은 수익률을 시현했다.

〈표 5〉 투자단계별 수익률 분포

\begin{tabular}{|c|c|c|c|c|c|}
\hline & \multirow[b]{2}{*}{$\mathrm{N}$} & \multicolumn{2}{|c|}{ IRR } & \multicolumn{2}{|c|}{ 투자배수 } \\
\hline & & 평균 & 중앙값 & 평균 & 중앙값 \\
\hline 투자 & 43 & $1.65 \%$ & $0.75 \%$ & 1.05 & 1.01 \\
\hline 회수 & 36 & $7.74 \%$ & $5.86 \%$ & 1.32 & 1.16 \\
\hline 미청산 & 9 & $-1.72 \%$ & $-0.15 \%$ & 0.98 & 0.99 \\
\hline 청산완료 & 46 & $10.57 \%$ & $10.77 \%$ & 1.35 & 1.34 \\
\hline (F값) 또는 [Chi-square 값 $]^{1)}$ & & $(8.42)^{* * *}$ & {$[29.21]^{* * *}$} & $(9.97)^{* * *}$ & {$[33.32]^{* * *}$} \\
\hline
\end{tabular}

주) 1) IRR 및 투자배수의 평균에 대한 투자단계별 동일성 여부는 F값을 통해, IRR 및 투자배수의 중앙값에 대한 투자단계별 동일성 여부는 Kruskal-Wallis 검정결과 도출된 chi-square 값을 통해 판단한다. <표 6>, <표 7>, <표 8>의 F값과 Chi-square 값은 각각 투자전략, 투자시기, 펀드규모별 동일성 여부를 검증한 결과 도출된 값이다.

이 같이 청산이 완료되지 않은 펀드들이 청산펀드에 비해 수익률이 낮게 나타나는 이유는 투자기업의 가치를 증대시키는 활동이 충분히 이루어지지 않았기 때문으로 해석할 수 있다. 즉 $\mathrm{PEF}$ 의 경우 일반적으로 투자가 완료된 이후 시점부터 기업가치 증대를 위한 활동을 본격적으로 진행하기 때문이다. 또한 $\mathrm{GP}$ 들이 최종 수익률 확정 전까지는 보유자산에 대해 평가를 보수적으로 보고하는 것도 한 이유로 추론할 수 있다.

\section{1 .2 투자전략별}

투자전략별 수익률 분포결과는 <표 6>에 정리되어 있다.

분석결과 바이아웃펀드의 수익률이 타 전략 펀드들에 비해 월등히 높았다. 바이아웃펀드의 IRR은 평균 $8.03 \%$, 투자배수는 평균 1.28 로 $\mathrm{PEF}$ 평균 수익률을 크게 초과했다. 이어 재무안정 펀드가 IRR $6.80 \%$, 투자배수 1.15 로 바이아웃펀드의 뒤를 이었다. 반면 성장펀드와 자원개발 등 기타전략 펀드들의 수익률은 상대적으로 저조했다. 투자전략별 수익률의 차이는 투자배수가 IRR에 비해 통계적으로 더 유의하게 나타났다. 투자배수는 평균이나 중앙값 모두 투자전략별로 통계적 유의성을 보인반면 IRR은 평균의 경우에만 유의성을 나타냈다.

〈표 6〉 투자전략별 수익률 분포

\begin{tabular}{|c|c|c|c|c|c|}
\hline & \multirow[b]{2}{*}{$\mathrm{N}$} & \multicolumn{2}{|c|}{ IRR } & \multicolumn{2}{|c|}{ 투자배수 } \\
\hline & & 평균 & 중앙값 & 평균 & 중앙값 \\
\hline 바이아웃 & 82 & $8.03 \%$ & $6.04 \%$ & 1.28 & 1.19 \\
\hline 성장 & 44 & $2.84 \%$ & $2.77 \%$ & 1.12 & 1.04 \\
\hline 재무안정 & 3 & $6.80 \%$ & $6.15 \%$ & 1.20 & 1.15 \\
\hline 기타 & 5 & $3.23 \%$ & $3.03 \%$ & 1.14 & 1.10 \\
\hline (F값) 또는[Chi-square 값] & & $(2.52)^{*}$ & {$[5.62]$} & $(3.33)^{*}$ & {$[6.64]^{*}$} \\
\hline
\end{tabular}


이 같이 바이아웃펀드들의 수익률이 타 전략펀드보다 우수하게 나타난 이유는 국내 $\mathrm{PEF}$ 가 바이아웃 펀드를 모델로 도입되었기 때문으로 해석할 수 있다. $\mathrm{PEF}$ 의 경우 투자기업에 대해 $10 \%$ 이상 지분을 투자해야 하는 운영규정으로 인해 $\mathrm{CB}$ 나 $\mathrm{BW}$ 등 메자닌방식을 통한 운용 등에 제약이 있었다. 또한 사모자본시장이 아직은 걸음마 단계로 다른 전략을 활용할만한 시장환경이 조성되지 못한 것도 다른 이유로 추론할 수 있다.

\section{1 .3 투자시기별}

국내에 PEF가 2004년에 도입됨에 따라 PEF 시장을 발전단계에 따라 준비기(2004 2007), 도약기(2008 2011), 성장기(2012 2017)로 구분하기도 한다. 이 같이 PEF 시장의 발전단계별로 운용능력이 향상되었는가를 검증하기 위해 투자시기별 성과차이를 분석했다.

〈표 7〉 투자시기별 수익률 분포

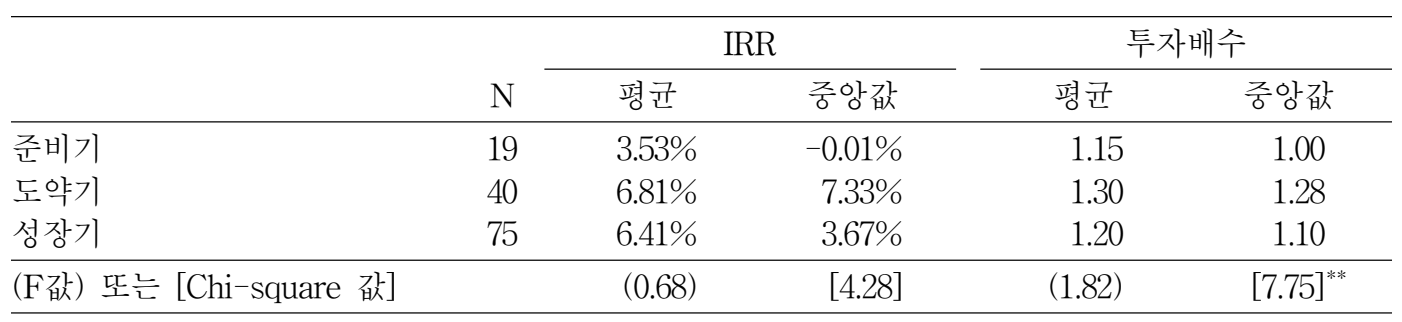

분석결과 <표 $7>$ 에서와 같이 도약기와 성장기의 수익률은 유사하게 높은 반면 준비기의 수익률은 낮은 것으로 나타났다. 도약기의 경우 IRR $6.81 \%$, 투자배수 1.30 을, 성장기의 경우에는 IRR $6.41 \%$ 투자배수 1.20 을 기록했다. 하지만 투자시기별 성과차이는 평균의 경우 IRR이나 투자배수 모두 통계적으로 유의하지 않았다. 즉 $\mathrm{PEF}$ 투자성과는 최초 준비기를 제외하고는 시장 발전정도와는 관련성이 없다고 할 수 있다. 다만 투자배수 중앙값의 경우에는 $5 \%$ 수준에서 시기별로 차이가 존재하는 것으로 밝혀졌다.

\section{1 .4 펀드규모별}

펀드규모별로도 수익률의 차이가 존재하는지 분석해 보았다. $\mathrm{PEF}$ 의 경우 일반적으로 약정액 기준으로 3 천억 원 이상이면 대형, 1 천억 원에서 3 천억 원 사이면 중형, 1 천억 원 미만이면 소형으로 구분되고 있어 이 기준을 이용하여 펀드규모를 구분하였다.

분석결과 <표 8>에서 보는 바와 같이 소형펀드가 대형펀드보다 수익률이 더 높았다. 소형 펀드의 IRR은 9.14\%, 투자배수는 1.29 를 기록하여 대형펀드에 비해 IRR은 3배 정도, 투자배수도 0.14 가 더 높았다. 반면 IRR 중앙값의 경우에는 중형펀드가 소형펀드보다 더 높아 소형펀드 중 일부펀드가 상당히 높은 수익률을 시현한 것으로 나타났다. 이에 따라 IRR의 경우에는 평균이나 중앙값 모두 펀드규모별로 수익률 차이가 발생하는 것으로 밝혀졌다. 하지만 투자배수의 경우에는 IRR만큼 펀드규모별로 차이를 보이지 않아 규모별 차이가 통계적으로 유의하게 존재하지 않은 것으로 나타났다. 
Performance of Private Equity Funds in Korea

〈표 8〉 펀드규모별 수익률 분포

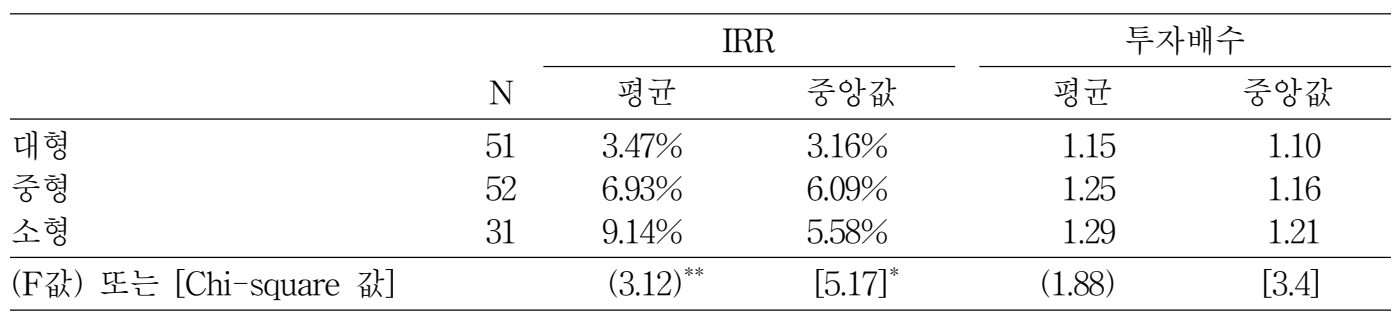

이 밖에 GP별로 성과의 지속성이 존재하는지 검증하려 했으나 자료의 부족으로 유의한 분석을 실시하지 못했다. 예컨대 2개 이상의 펀드에 대해 청산을 완료한 GP는 12 개사에 불과했다12). 이 중 $\mathrm{IMM}$ 이 6개로 가장 많은 펀드를 청산완료했으며 스카이레이크가 5개 펀드를 청산완료했다. 펀드를 성공적으로 청산한 $\mathrm{GP}$ 의 수익률이 높아 IMM의 경우 평균 IRR $20.06 \%$, 투자배수 1.59 를 기록했으며 스카이레이크도 평균 IRR $15.6 \%$, 투자배수 1.43 을 기록했다.

\section{2 청산완료 펀드 분석}

$\mathrm{PEF}$ 의 경우 뮤추얼펀드나 헤지펀드와는 달리 기간 수익이 별다른 의미를 갖지 못한다. 대부분의 경우 자금모집과 투자 기간을 거친 후 회수단계에서 수익을 창출하기 때문이다. 더구나 청산 전 LP들에게 제공하는 IRR이나 투자배수 실적은 시장성이 없는 보유자산에 대한 평가액이 포함되어 있어 그 값에 신뢰성을 담보하기 어렵다. 청산이후 수익률이 보다 의미를 갖게 되는 이유이다. Kaplan and Schoar(2005)나 Phalippou and Gottschalg(2009) 등 PEF와 관련된 대표적인 해외 연구의 경우에도 대부분 청산이 되었거나 최종 현금 흐름 발생 후 상당기간이 경과하여 청산으로 간주되는 펀드들을 대상으로 분석을 실시했다.

이에 따라 본 연구에서도 청산완료된 46개 펀드만을 대상으로 수익률 분석을 다시 실시했다. 청산완료 펀드의 IRR와 투자배수는 <표 5>에서 이미 기술하였고 펀드규모는 평균 1,826 억 원으로 총 표본의 2.658억보다 작았다. 이는 초기 $\mathrm{PEF}$ 가 소규모였음을 의미한다고 할 수 있다. 청산완료 펀드들을 대상으로 시장수익률 비교 우위여부, 경기순환주기에 따른 수익률, 그리고 $\mathrm{GP}$ 의 과대보고 유인에 대한 분석을 실시했다.

\subsection{1 위험조정수익률}

위험조정 수익률은 방법론에서 살펴본 바와 같이 $\mathrm{KS}-\mathrm{PME}, \mathrm{PME}+$, 다이렉트 알파 방법을 통해 산출했다. 다만 벤치마크를 감안한 방법을 활용하기 위해서는 $\mathrm{PEF}$ 의 현금흐름에 대한 자료가 존재해야 한다. 따라서 46 개 청산펀드 중 현금흐름 자료를 확보한 30 개 펀드에 대해서만 분석을 실시했다.

분석결과 <표 9>에서와 같이 청산된 $\mathrm{PEF}$ 의 성과는 시장보다 평균적으로 우수한 것으로 밝혀졌다. 코스피를 벤치마크로 한 경우 $\mathrm{KS}-\mathrm{PME}$ 의 평균값은 1 을 초과한 1.23 을 기록했고

12) H\&Q, IMM, KDB캐피탈, KTB PE, MVP, 글렌우드, 미래에셋파트너스, 스카이레이크, 신한 PE, 우리 $\mathrm{PE}$, 커넥스파트너스, 코너스톤 $\mathrm{PE}$. 
$\mathrm{PME}+$ 는 0을 초과한 0.04 를, 다이렉트 알파는 $9.82 \%$ 를 기록했다. 모든 방식에서 시장수익률을 앞선 것이다. 또한 코스닥을 벤치마크로 활용한 경우에도 모두 시장수익률을 상회했다. 특히 다이렉트 알파방법을 제외하고는 모두 코스닥을 벤치마크로 활용한 경우가 수익률이 소폭 더 높았다. 중앙값의 경우에도 $\mathrm{KS}-\mathrm{PME}, \mathrm{PME}+$, 다이렉트 알파 등 모든 방법론에서 코스피와 코스닥을 시장지수로 활용한 경우 시장수익률보다 높았으며 코스닥을 벤치마크로 활용한 경우 수익률이 더 높았다. 이에 따라 시장 초기 국내 $\mathrm{PEF}$ 성과는 주식시장 수익률을 상회했다고 결론지을 수 있다.

〈표 9〉벤치마크를 고려한 PEF 수익률

\begin{tabular}{llrrrr}
\hline 시장지수 & \multicolumn{1}{c}{ 방법론 } & 평균 & 중앙값 & 최소값 & 최대값 \\
\hline \multirow{3}{*}{ 코스피 } & $\mathrm{KS}-\mathrm{PME}$ & 1.23 & 1.02 & 0.50 & 6.60 \\
& $\mathrm{PME}+$ & 0.04 & 0.02 & -0.17 & 0.27 \\
& 다이렉트 알파 & $9.82 \%$ & $0.51 \%$ & $-38.7 \%$ & $319.9 \%$ \\
\hline \multirow{3}{*}{ 코스닥 } & $\mathrm{KS}-\mathrm{PME}$ & 1.28 & 1.10 & 0.60 & 6.60 \\
& $\mathrm{PME}+$ & 0.05 & 0.03 & -0.17 & 0.60 \\
& 다이렉트 알파 & $9.60 \%$ & $1.70 \%$ & $-86.2 \%$ & $318.3 \%$ \\
\hline
\end{tabular}

\subsection{2 경기순환주기에 따른 수익률}

$\mathrm{PEF}$ 수익률은 경기순환과정과 밀접한 관련성이 있는 것으로 조사되고 있다. $\mathrm{PEF}$ 는 주로 내재가치를 제대로 평가하지 못하는 비상장 기업의 지분에 투자한 후 가치가 상승한 시점에 지분을 매각하거나 $\mathrm{IPO}$ 를 통해 투자금을 회수한다. 따라서 $\mathrm{PEF}$ 는 경기가 침체되어 저평가된 비상장기업을 취득할 기회가 많을 시기가 최적 투자시점이며 경기가 호황기에 접어들어 주식시장이 최고점에 달할 때가 최적 회수시점이 된다. 이 같은 전략을 통한 수익창출 과정은 다른 투자상품과 동일하겠지만 $\mathrm{PEF}$ 의 경우 투자는 가치평가가 어려운 비상장기업을 대상으로, 회수는 상장기업을 통해 이루어진다는 측면에서 경기변동에 더 민감할 수 있다. Robinson and Sensoy(2013)는 PE 수익률과 경기순환시기에 대한 관계를 분석, 경기 과열 시 모집된 자금의 수익률이 열악한 경기상황에서 모집된 자금의 수익률보다 낮다는 사실을 밝혀냈다. 2011년 이후 미국 $\mathrm{PE}$ 의 수익률이 급격히 상승한 이유도 글로벌 금융위기 전후로 모집된 펀드들이 경기활황기에 맞추어 본격적인 회수단계에 접어들었기 때문으로 풀이된다.

이에 따라 본 절에서는 경기순환 주기에 따른 $\mathrm{PEF}$ 의 수익률을 분석했다. 다만 국내 $\mathrm{PEF}$ 시장의 역사가 일천하여 경기순환 주기를 투자시점과 청산시점 모두가 아닌 청산시점만을 기준으로 삼았다. 짧은 주기에 한 시점만을 선택해야 한다면 투자시점보다 청산시점이 더 합리적일 것이기 때문이다. 즉 투자시점의 지분매수는 경제상황이나 잠재적 경쟁자들과의 경쟁환경, 자금조달 시장의 상황 등에 따라 변동성이 큰 반면 지분매도는 주식시장을 통해 이루어지는 경우가 많아 경기와의 연관성이 보다 뚜렷할 것이다. 경기순환주기는 동행종합지수와 선행종합 지수 등 경기종합지수를 활용한다. 하지만 $\mathrm{PEF}$ 의 정확한 회수시점을 월단위로 파악하기 어려워 연평균을 산출해 100 이상을 호황기로, 100 이하를 불황기로 구분하였다. 
Performance of Private Equity Funds in Korea

〈표 10〉경기순환주기에 따른 수익률 분포

\begin{tabular}{lllrr}
\hline & $\mathrm{N}$ & \multicolumn{1}{c}{$\mathrm{IRR}$} & 투자배수 \\
\hline \multirow{4}{*}{ 동행종합지수 } & 100 이상 & 34 & $9.61 \%$ & 1.32 \\
& 100 이하 & 12 & $13.29 \%$ & 1.43 \\
& 차이분석(t) & & $(-0.92)$ & $(-0.90)$ \\
\hline \multirow{3}{*}{ 선행종합지수 } & 100 이상 & 25 & $8.43 \%$ & 1.28 \\
& 100 이하 & 21 & $13.13 \%$ & 1.41 \\
& 차이분석(t) & & $(-1.35)$ & $(-1.41)$ \\
\hline
\end{tabular}

분석결과 <표 $10>$ 에서와 같이 경기종합지수가 100 이하로 떨어져 불황인 시기에 청산된 $\mathrm{PEF}$ 의 수익률이 더 높은 것으로 밝혀졌다. IRR이나 투자배수 모두 동행종합지수나 선행종합지수 100 이하의 불황인 시기에 청산된 경우가 100 이상의 호황인 시기에 청산된 경우보다 통계적으로 유의하지는 않았지만 수익률이 더 높게 나타났다. 이 같이 불황기에 청산이 이루어진 경우 수익률이 더 높게 나타난다는 사실은 $\mathrm{PEF}$ 가 대체자산으로서 역할을 수행할 수 있는 자산군의 역할을 할 수 있다는 점에서 흥미로운 결과라고 할 수 있다.

\subsubsection{GP 과대보고 유인에 대한 분석}

$\mathrm{GP}$ 들은 일반적으로 운용하고 있는 펀드에 대한 성과를 과대보고 할 유인을 가지고 있다. 즉 $\mathrm{PEF}$ 시장에서 $\mathrm{GP}$ 의 운용실적(track record)은 $\mathrm{LP}$ 들이 투자여부를 결정하는데 고려하는 주요 지표 중 하나이기 때문이다. 특히 최근 $\mathrm{GP}$ 들의 펀드 재설정 비율이 증가하면서 성과에 대한 과대보고 유혹은 더욱 강해지고 있다. Brown et al.(2019)도 GP들이 후속펀드를 만드는 경우 투자약정을 받기 위해 현재 운용하고 있는 펀드의 성과를 과대 보고할 유인을 갖는다고 밝힌 바 있다. 즉 $\mathrm{GP}$ 들은 객관적으로 평가하기 어려운 자산을 보유하고 있으므로, 자신들에게 이익이 되는 경우 보유한 자산 가치를 과대 보고할 여건이 갖추어져 있으며, 특히 후속펀드 설정을 위해 자금을 조달할 경우 그 가능성이 더욱 증대된다는 것이다.

이에 따라 본 절에서는 국내 시장에서도 $\mathrm{GP}$ 들의 $\mathrm{PEF}$ 성과 과대보고 현상이 관찰되는지 검증했다. 기본적으로 이 같은 분석을 정교하게 하기 위해서는 자금을 연속적으로 조달하는 시리즈(sequence)펀드가 존재해야 한다. 하지만 국내 $\mathrm{PEF}$ 시장의 경우 시리즈펀드에 대한 자료가 제한적이다. 따라서 본 연구에서는 청산완료된 펀드를 대상으로 $\mathrm{GP}$ 들이 청산 이전에 보유한 포트폴리오의 수익률 추정치에 대해 과대 보고하는지의 여부를 검증함으로써 성과 과대보고 현상을 간접적으로 검증했다.

청산완료된 46개 $\mathrm{PEF}$ 중 청산 이전에 한 번 이상 의미 있는 IRR이나 배수 자료를 보고한 펀드는 총 28 개이다. 이들을 대상으로 청산 3 년 전 $(n-3)$ 부터 청산시점 $(n)$ 까지 보고한 IRR과 투자배수의 추이를 살펴보았다. 분석결과 <그림 4 >에서 보는 바와 같이 IRR이나 투자배수 모두 과대보고 하는 양태를 보이지 않았다. IRR의 경우 청산완료 2 년 전 $(n-2)$ 에 $7.62 \%$ 로 다소 높은 IRR을 보고하는 것으로 나타났으나 청산완료 시점의 IRR인 $7.28 \%$ 와 큰 차이를 보이지는 않았다. 투자배수의 경우에는 오히려 청산완료 시점이 1.25 로 가장 높아 $\mathrm{GP}$ 의 과대보고는 국내 $\mathrm{PEF}$ 시장에서는 아직 발견되지 않는 것으로 나타났다. 
〈그림 4〉 청산완료 전 IRR와 배수 변동 추이

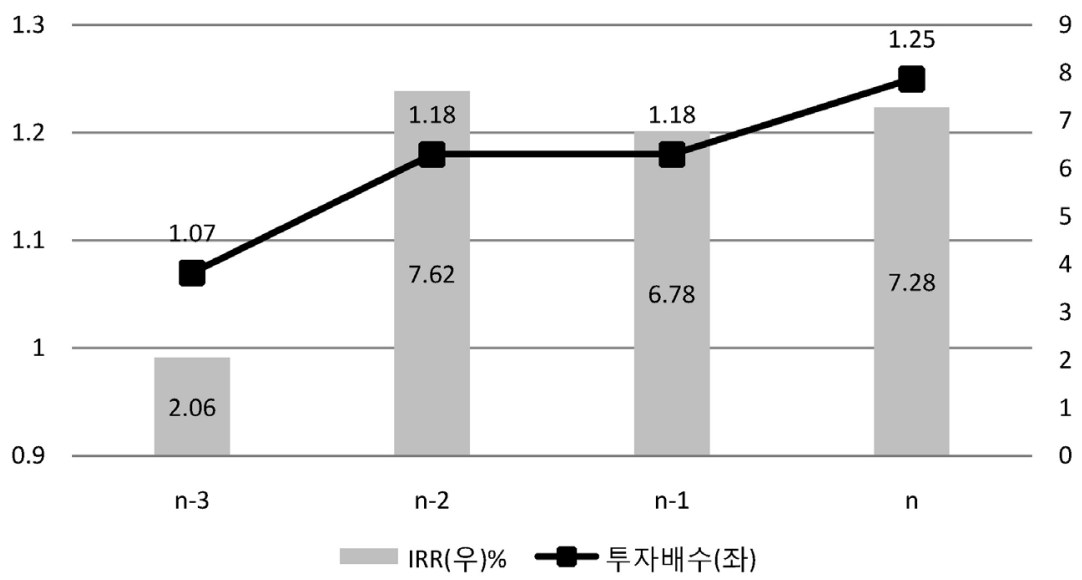

$\mathrm{GP}$ 들이 성과를 과대보고 하지 않는 이유는 국내 $\mathrm{PEF}$ 시장의 독특한 구조때문으로 풀이된다. 국내 $\mathrm{PEF}$ 의 경우 국민연금을 포함한 연기금들이 주요 $\mathrm{LP}$ 역할을 담당함에 따라 $\mathrm{GP}$ 들은 평판 위험에 상당히 민감하다. 즉 자금을 지속적으로 조달해야 하는 GP 입장에서는 일회성 자금 모집을 위해 성과를 과대로 보고할 유인이 적을 수밖에 없는 것이다. 또한 연기금들이 상당한 수준의 전문성을 보유하고 있어 왜곡 보고의 개연성이 떨어지는 것도 또 다른 이유로 추론할 수 있다.

\section{3 수익률에 미치는 요인 분석}

본 절에서는 $\mathrm{PEF}$ 의 수익률에 영향을 미치는 요인들에 대한 분석을 실시한다. Aigner et $\mathrm{al}$ (2008)은 $\mathrm{PE}$ 중 바이아웃 딜의 비중, $\mathrm{GP}$ 의 경험, $\mathrm{GP}$ 관리펀드 수, 펀드 수명, 자금규모, 현금흐름, 설정년도 및 펀드 수명기간 동안의 시장 수익률·GDP 명목 성장률·T-bill 3개월 금리 등의 변수를 활용해 수익률에 미치는 영향을 분석했다. 본 연구에서도 해당 변수를 활용해 분석을 실시하고자 했으나 자료 획득의 한계 상 다음 식 (7)과 같이 Aigner et al.(2008)가 활용한 변수 중 일부만을 채택해 검증을 실시했다.

$$
\begin{aligned}
\operatorname{IRR}_{i}\left(\text { Mltiple }_{i}\right)= & \alpha+\beta_{1} M K T_{a v}+\beta_{2} M K T_{\text {open }}+\beta_{3} \text { VOL }_{a v}+\beta_{4} \text { Size }_{i} \\
& +\beta_{5} \text { Lifetime }_{i}+\beta_{6} G D P_{a v}+\beta_{7} T B_{a v}+\beta_{8} L Q_{i}+e_{i}
\end{aligned}
$$

여기서 $M K T_{a v}$ 는 펀드 수명기간 동안 코스피 또는 코스닥시장 수익률의 연평균값, $M K T_{\text {open }}$ 은 펀드 설정 시의 코스피 또는 코스닥 시장수익률, $V O L_{a v}$ 은 펀드 수명기간 동안 코스피 또는 코스닥 시장수익률의 변동성을 나타낸다. Size $e_{i}$ 는 펀드 약정액의 자연로그 값, Lifetime 은 펀드의 수명(설정년도에서 청산년까지의 기간), $G D P_{a v}$ 는 펀드 수명기간 동안 $\mathrm{GDP}$ 연평균 성장률, $T B_{a v}$ 는 펀드 수명기간 동안 국고채 3 년물의 연평균 수익률을 의미하며 $L Q_{i}$ 는 펀드의 청산여부(청산은 1 , 투자 및 회수단계는 0)을 나타내는 더미변수이다. 평균은 기하평균을 활용했으며 2017년 
Performance of Private Equity Funds in Korea

현재 투자 및 회수단계에 있는 펀드는 펀드수명을 2017년까지로 설정하였다. 시장수익률은 코스피와 코스닥 수익률을 각각 사용하였다. 총 표본 수는 미청산펀드 9 개를 제외한 125 개이다.

분석결과 펀드수명, 수명기간 동안의 시장수익률, 수명기간 동안의 GDP 성장률이 IRR 및 투자배수에 영향을 미치는 것으로 밝혀졌다. 펀드수명이 짧을수록, 수명기간 동안의 시장수익률이 낮을수록, 수명기간 동안의 $\mathrm{GDP}$ 성장률이 낮을수록 펀드의 수익률은 높았다. 이 같은 현상은 코스피 지수나 코스닥 지수를 이용한 경우 모두 공통적으로 나타났다. 반면 펀드의 규모, 설정시점의 시장수익률, 시장수익률의 변동성, 청산여부 등은 수익률에 별다른 영향을 미치지 못하는 것으로 밝혀졌다. 금리수준은 코스닥지수를 활용한 경우에 한해 금리가 낮을수록 펀드 성과가 좋은 것으로 나타났다.

〈표 11〉IRR 및 투자배수에 영향을 미치는 요인에 대한 회귀분석 결과

\begin{tabular}{|c|c|c|c|c|c|}
\hline & \multirow{2}{*}{ 변수 } & \multicolumn{2}{|c|}{ 코스피 } & \multicolumn{2}{|c|}{ 코스닥 } \\
\hline & & 계수 & $\mathrm{t}$ 값 & 계수 & $\mathrm{t}$ 값 \\
\hline \multirow{8}{*}{ IRR } & MKTav & -0.301 & $-2.88^{* * *}$ & -0.444 & $-2.73^{* * *}$ \\
\hline & MKTopen & 0.086 & 0.88 & 0.136 & 1.41 \\
\hline & VOLav & -0.027 & -0.32 & -0.036 & -0.42 \\
\hline & Size & -0.012 & -0.13 & -0.019 & -0.21 \\
\hline & Lifetime & -0.284 & $-3.02^{* * *}$ & -0.254 & $-2.68^{* * *}$ \\
\hline & GDPav & -0.165 & $-1.90^{*}$ & -0.169 & $-1.95^{*}$ \\
\hline & TBav & -0.202 & -1.59 & -0.389 & $-2.28^{* *}$ \\
\hline & LQ & 0.100 & 0.54 & 0.077 & 0.42 \\
\hline \multirow{8}{*}{ 투자배수 } & MKTav & -0.336 & $-3.20^{\text {**** }}$ & -0.584 & $-3.63^{* * *}$ \\
\hline & MKTopen & 0.075 & 0.76 & 0.115 & 1.20 \\
\hline & VOLav & -0.055 & -0.63 & -0.070 & -0.82 \\
\hline & Size & 0.004 & 0.05 & -0.008 & -0.08 \\
\hline & Lifetime & -0.179 & $-1.89^{*}$ & -0.153 & $-1.64^{*}$ \\
\hline & GDPav & -0.170 & $-1.94^{*}$ & -0.180 & $-2.09^{* *}$ \\
\hline & TBav & -0.069 & -0.54 & -0.352 & $-2.08^{* *}$ \\
\hline & LQ & 0.036 & 0.19 & 0.013 & 0.07 \\
\hline
\end{tabular}

$\mathrm{PEF}$ 수익률이 시장지수 및 GDP 성장률과 반비례를 보인 것은 Aigner et al.(2008)의 연구 결과와 상반된 것이어서 주목할 만하다. Aigner et al.(2008)은 다양한 독립변수의 활용여부에 따라 다소 상이하지만 대체적으로 $\mathrm{PE}$ 설정기간 동안의 시장수익률이나 $\mathrm{GDP}$ 성장률이 $\mathrm{PE}$ 의 $\mathrm{PME}$ 와 IRR에 양(+)의 영향을 미친다는 연구결과를 발표했다. 또한 $\mathrm{PE}$ 설정년도의 시장수익률 이나 GDP 성장률은 PME와 IRR에 음(-)의 영향을 미쳤다. Aigner et al.(2008)은 바이아웃 뿐 아니라 $\mathrm{VC}$ 도 모두 포함하는 $\mathrm{PE}$ 전체를 표본으로 하였고 글로벌펀드를 분석 대상으로 하였으나 시장수익률이나 GDP성장률은 지역별 지수를 활용한 점이 본 연구결과와 다소 상이한 결과를 도출한 이유로 추론할 수 있다. 이 같이 $\mathrm{PEF}$ 수익률이 시장지수 및 $\mathrm{GDP}$ 성장률과 반비례한다는 결과는 투자배수의 경우 채권수익률과 역관계를 보인 것과 함께 $\mathrm{PEF}$ 가 대체자산으로서의 역할을 수행할 수 있음을 보여주는 것으로 시사하는 바가 크다고 할 수 있다. 


\section{6. 결론 및 정책적 시사점}

본 연구는 경영참여형 사모펀드(PEF)의 성과를 분석하였다. 연기금 등 대표적인 기관투자자 (LP)로부터 실제 투자내역을 직접 수집한 독점적 수익률 자료를 토대로 134 개 $\mathrm{PEF}$ 에 대해 투자단계별·투자전략별·투자시기별·펀드규모별 성과차이를 분석하였다. 또한 청산완료된 46개 $\mathrm{PEF}$ 를 대상으로 위험조정수익률·경기순환에 따른 수익률· $\mathrm{GP}$ 과대보고유인 등에 대한 검증을 실시했다. 이와 함께 $\mathrm{PEF}$ 수익률에 미치는 요인에 대한 분석도 실시했다.

분석결과 국내 $\mathrm{PEF}$ 의 평균 $\mathrm{IRR}$ 은 $6.12 \%$, 투자배수는 1.22 를 기록하여 양호한 수준의 수익률을 시현한 것으로 밝혀졌다. 투자단계별로는 청산완료된 펀드가, 투자전략별로는 바이아웃 펀드의 수익률이 가장 높았으며 규모별로는 소규모 펀드의 수익률이 상대적으로 우수했다. 대부분의 수익이 회수시점에 실현되는 $\mathrm{PEF}$ 의 특성 상 청산완료된 펀드만을 대상으로 성과분석을 실시한 결과, $\mathrm{KS}-\mathrm{PME}, \mathrm{PME}+$, 다이렉트 알파 등 위험조정수익률을 산출하는 모든 지표에서 수익률이 시장수익률을 초과하는 것으로 나타났다. 경기순환주기에 대한 분석에서는 불황시기에 청산된 펀드의 수익률이 더 높았다. $\mathrm{PEF}$ 수익률에 미치는 영향에 대한 분석 결과, 펀드수명이 짧을수록, 수명기간 동안의 시장수익률과 GDP 성장률이 낮을수록 수익률이 높은 것으로 밝혀졌다.

본 연구의 경우 표본기간이 짧고 표본 수가 많지 않아 결과에 대한 신뢰성을 완전히 담보하기는 어렵다. 특히 자료 제약 상 $\mathrm{PEF}$ 전체를 대상으로 하지 못하고 일부 $\mathrm{LP}$ 자료만을 활용해 결과의 편의성이 존재할 가능성도 있다. 또한 2017년 말 기준으로 운용 중인 펀드의 수명기한을 2017년 으로 한정지은 사실도 펀드 수명과 수익률간의 관계와 관련된 결과의 오류 가능성을 내포할 수 있다. 그럼에도 불구하고 본 연구는 $\mathrm{PEF}$ 수익률 분석에 대한 최초의 연구라는 점에서 상당한 공헌점이 있으며 다음과 같은 정책적 시사점을 제시한다고 할 수 있다.

먼저 사모펀드 활성화 정책은 지속되어야 한다는 점이다. 연구결과에서 본 바와 같이 $\mathrm{PEF}$ 성과는 시장수익률을 초과하는 것으로 나타났다. 특히 주식시장 하락기 또는 GDP 성장률 저하 시 오히려 수익률이 더 높게 나타나 대체자산으로서의 역할을 수행할 수 있는 것으로 밝혀졌다. 사모펀드 시장의 확대는 전 세계의 공통된 현상으로 투자의 사모화, 패시브화, 기관투자자화는 피할 수 없는 자본시장의 흐름이다. 저금리, 저성장 시대에 중수익을 원하는 투자자 관점이나, 정책자금 만으로는 공급이 부족한 모험자본 시장에서 민간 자본의 공급을 필요로 하는 금융당국 관점에서도 사모펀드 시장은 성장세를 지속해 나가야 할 것이다.

다만 최근의 코링크PE 사태에서 보는 바와 같이 사모펀드 규제완화에 대한 속도조절은 필요할 것으로 판단된다. 금융당국은 2015년 이후 사모펀드 규제를 지속적으로 완화, 전문사모운용사의 경우 현재 자본금 10 억 원만 있으면 등록제를 통해 자금운용을 할 수 있다. 이와 같이 진입장벽을 낮추다 보니 운용사가 우후죽순으로 설립되면서 여러 가지 부작용이 발생하고 있다. 펀드가 소형화되고 운용시기도 단기화되어 모험자본 공급 역할을 제대로 수행하지 못하는 경향이 있다. 또한 운용사의 투자상품에 대한 쏠림현상이 발생하면서 시장 질서를 어지럽히고 있다. 예컨대 메자닌 펀드가 급증하면서 $\mathrm{CB}$ 나 $\mathrm{BW}$ 발행 부적격기업까지 이에 가세, 과다한 물량이 시장에 쏟아져 나온 바 있다. 최근 환매가 중단되어 투자자 피해로 이어진 펀드의 경우도 결국 메자닌에 주로 투자한 것으로 알려지고 있다. 무엇보다도 소형 운용사는 수익 창출이 어렵다 보니 여러 
Performance of Private Equity Funds in Korea

가지 불법적인 유혹에 빠지는 것으로 밝혀지고 있다. 가장 대표적인 것이 판매사가 펀드의 투자대상.시기·금액·조건을 정하고 운용사에 운용을 지시하는 소위 $\mathrm{OEM}$ 펀드이다. 자산 운용사는 판매사와의 이면계약에 따라 그 판매업자의 명령·지시·요청 등을 받아 펀드를 운용해서는 안 된다13). 하지만 판매채널이 없는 특히 소형 운용사 입장에서는 펀드를 손쉽게 모집하고 별 다른 노력 없이 운용수수료를 고정적으로 챙길 수 있다는 측면에서, 판매사는 보유하고 있는 증권의 유통을 원활하게 할 수 있다는 측면에서 $\mathrm{OEM}$ 펀드 판매가 공공연하게 이루어지고 있다. 또한 $\mathrm{LP}$ 는 $\mathrm{GP}$ 업무에 관여해서는 아니 됨에도 운용지시 등의 불법행위가 적발되기도 한다. ${ }^{14}$

본 연구는 투자자나 운용자에게 $\mathrm{PEF}$ 성과 관련 정보를 제공한다는 점에서도 의의가 있다. 연구결과를 통해 운용기간이나 투자전략에 따른 수익률 차이를 인식함에 따라 최적의 운용기간 이나 전략을 모색할 수 있을 것이다. 특히 투자전략의 다양화 필요성을 제기했다고 할 수 있다. 연구결과 바이아웃과 재무안정 전략을 활용하고 있는 $\mathrm{PEF}$ 의 수익률이 높게 나타났지만 이는 세컨더리나 자원개발 등 다양한 종류의 전략을 활용할 시장여건이 조성되지 않았기 때문으로 향후 이들 영역에 대한 다양한 전략 도입 필요성을 제기했다. 또한 다양한 위험조정수익률 측정 방법을 소개함으로써 단순한 IRR이나 투자배수를 통한 수익률 개념에서 벤치마크를 고려한 상대적 수익도 측정가능하게 하였다.

본 연구는 또한 $\mathrm{PEF}$ 의 지배구조 개선에 대한 역할론도 시사한다. $\mathrm{PEF}$ 와 지배구조에 대한 관련성을 직접 분석하지는 않았지만 $\mathrm{PEF}$ 성과 측정을 통해 간접적으로나마 스튜어드십 코드 확산 추세에 따른 행동주의적 $\mathrm{PEF}$ 의 등장 필요성에 대한 논의를 제기할 수 있을 것으로 기대한다. $\mathrm{PEF}$ 의 핵심적 역할 중 하나는 투자 기업에 대한 가치제고이다. 현재 국내 $\mathrm{PEF}$ 는 바이아웃에 방점이 찍혀있는 상황으로 바이아웃펀드의 주 목적은 지분 인수 후 다양한 방법의 밸류업 전략을 통해 가치를 증대시킨 후 지분 매각을 통해 수익을 창출하는 것이다. 밸류업 전략을 실행하기 위한 경영개편 과정에서 자연스럽게 지배구조 개선이 이루어진다. 따라서 수익률이 높은 $\mathrm{PEF}$ 의 경우 지배구조 개선이 뒤따를 수 있는 것이다. 실제 $\mathrm{PEF}$ 의 지배구조 개선 사례는 본 연구의 범위를 벗어나지만 해당 주제에 대한 관심을 제기했다는 점에서 의의가 있다고 할 수 있다.

마지막으로 본 연구는 $\mathrm{PEF}$ 관련 정보의 공시 필요성을 제기한다. 현재 $\mathrm{PEF}$ 자료는 공식적으로 공개되지 않는다. 금융감독원에서 $\mathrm{GP}$ 들에게 1년에 1 2차례 정기보고서를 징구하는 수준이다. 정기보고서 내용도 펀드 개황이나 GP 현황, 약정액·실행액, 투자기업과 투자형태, 그리고 차입비율 정도에 그친다. 운용성과나 LP에 대한 정보는 금융당국에서도 집계하지 않고 있다. 이에 따라 투자자, 연구자, 심지어 동종 업계에서도 $\mathrm{PEF}$ 설립과 청산, 투자자, 운용성과 등과 관련된 정보 접근이 거의 불가능하다. 반면 해외의 경우 Venture Economics나 Cambridge Associates, 또는 Burgiss에서 개별 바이아웃 $\mathrm{PEF}$ 나 $\mathrm{VC}$ 에 대한 구체적 자료를 제공하고 있다. 따라서 $\mathrm{PEF}$ 시장의 건전한 발전을 도모하기 위해서는 객관적 기록에 대한 정보 공개가 우선되어야 할 것으로 생각한다.

13) 자본시장법 제 85 조제 8 호, 자본시장법 시행령 제 87 조제 4 항제 6 호.

14) 자본사장법 제 249 조의 11 제 4 항. 
한국증권학회지 제49권 2호 (2020)

\section{References}

Aigner, P., S. Albrecht, G. Beyschlag, T. Friederich, M. Kalepky, and R. Zagst, 2008, What Drives PE?: Analyses of Success Factors for Private Equity Funds, Journal of Private Equity, Vol. 11, pp. 63-85.

Brown, G., O. Gredil, and S. Kaplan, 2019, Do Private Equity Funds Manipulate Reported Returns?, The Journal of Financial Economics, Vol. 132, pp. 267-297.

Financial Supervisory Service(FSS), 2019, Trends and Implications of Private Equity Funds in 2018 .

Financial Services Commission(FSC), 2015, Amendment to the Capital Market Consolidation Act to Activate Private Funds.

Gredil, O., B. Griffiths, and R. Stucke, 2014, Benchmarking Private Equity: The Direct Alpha Method, SSRN Working Paper.

Harris, R., T. Jenkinson, and S. Kaplan, 2014, Private Equity Performance: What Do We Know?, Journal of Finance, Vol. 69, pp. 1851-1882.

Higson, C., and R. Stucke, 2012, The Performance of Private Equity, London Business School Working Paper.

Kaplan, S., and A. Schoar, 2005, Private Equity Performance, Returns, Persistence, and Capital Flows, Journal of Finance, Vol. 60, pp. 1791-1823.

Lee, K., and C. Han, 2013, Performance and Risk Profile of Private Equity Funds and Private Equity Fund-of-Funds in Korea, Korean Journal of Financial Studies, Vol. 42 (1), pp. $47-78$.

Park, J., and B. Yoon, 2012, A Study on the Current Situation and the Performance of KFoF(Korea Fund of Funds), Asia Pacific Journal of Small Business, Vol. 34 (2), pp. 23-46.

Phalippou, L., and O. Gottschalg, 2009, The Performance of Private Equity Funds, Review of Financial Studies, Vol. 22, pp. 1747-1776.

Preqin, 2019, Alternatives in 2019.

Song, I., J. Kang, and C. Yun, 2014, Private Equity Fund Performance and Persistency by Fund Type, Korean Journal of Futures and Options, Vol. 22 (3), pp. 531-564.

Song, I., J. Park, and M. Choi, 2015, The Performance of Private Equity Funds and Its Diversification Effect, Asian Review of Financial Research, Vol. 28 (3), pp. 385-416. Robinson, D., and B. Sensoy, 2013, Do Private Equity Fund Managers Earn their Fees? Compensation, Ownership, and Cash Flow Performance, Review of Financial Studies, Vol. 26, pp. 2760-2797. 
Performance of Private Equity Funds in Korea

Rouvinez, C., 2003, Private Equity Benchmarking with $\mathrm{PME}^{+}$, Venture Capital Journal, Vol. 5, pp. 34-38.

Yi, J., 2017, Performance Analyses of Private Funds: From an Alternative Investment Perspective, Korean Journal of Financial Studies, Vol. 46 (1), pp. 187-216.

Yi, J., 2019, The impact and implication of asset under management growth on stability of financial market-focusing on private funds, Working Paper, Bank of Korea. 
한국증권학회지 제49권 2호 (2020)

〈부록 1〉 $\mathrm{PEF}$ 설정년도별 투자단계 현황

\begin{tabular}{|c|c|c|c|c|c|c|}
\hline \multicolumn{2}{|c|}{ 구분 } & 투자 & 회수 & 미청산 & 청산완료 & 소계 \\
\hline \multirow{13}{*}{ 설정년도 } & 2005 & 0 & 0 & 3 & 5 & 8 \\
\hline & 2006 & 0 & 0 & 1 & 3 & 4 \\
\hline & 2007 & 0 & 0 & 3 & 4 & 7 \\
\hline & 2008 & 0 & 3 & 1 & 3 & 7 \\
\hline & 2009 & 0 & 1 & 0 & 3 & 4 \\
\hline & 2010 & 0 & 9 & 0 & 9 & 18 \\
\hline & 2011 & 0 & 6 & 0 & 5 & 11 \\
\hline & 2012 & 0 & 11 & 0 & 3 & 14 \\
\hline & 2013 & 3 & 6 & 0 & 3 & 12 \\
\hline & 2014 & 15 & 0 & 0 & 3 & 18 \\
\hline & 2015 & 9 & 0 & 1 & 4 & 14 \\
\hline & 2016 & 12 & 0 & 0 & 1 & 13 \\
\hline & 2017 & 4 & 0 & 0 & 0 & 4 \\
\hline & & 43 & 36 & 9 & 46 & 134 \\
\hline
\end{tabular}

